\title{
МЕДІА- ТА ІНФОРМАЦІЙНА ГРАМОТНІСТЬ ЯК СТРАТЕГІЧНИЙ НАПРЯМ У ДІЯЛЬНОСТІ ЮНЕСКО
}

\author{
Приходькіна Н. О. \\ кандидат педагогічних наук, доиент, \\ професор кафедри педагогіки, адміністрування і спеціальної освіти \\ ДВНЗ «Університет менеджменту освіти» Національної академї педагогічних наук Украӥни \\ вул. Січових стрільців, 52-А, Київ, Україна \\ orcid.org/0000-0002-6211-5546 \\ prykhodkina2019@gmail.com
}

Ключові слова: медіа, медіа- та інформаційна грамотність, ЮНЕСКО, ООН, декларація, резолюиія.

\begin{abstract}
Авторкою проаналізовано ключові документи конференцій ЮНЕСКО, що сприяли розвитку медіа- та інформаційної грамотності у світі. ЮНЕСКО у своїй діяльності підкреслює роль медіаграмотності як найважливішої компетенції цифрової епохи. У середині 70-х років ЮНЕСКО заявило не тільки про свою повну підтримку медіаосвіти, а й про медіаосвіту як про пріоритетний напрям на найближчі десятиліття. Вважається, що термін «медіаосвіта» офіційно на світовому рівні вперше було використано у 1973 р. у процесі спільного засідання Сектору інформації ЮНЕСКО та Міжнародної ради 3 кіно та телебачення. У деклараціях та резолюціях міжнародних конференцій ЮНЕСКО підкреслює важливість цього напряму і визначає медіаосвіту як один 3 пріоритетних напрямів своєї діяльності. Дослідницею проаналізовано зміст декларацій, резолюцій та рекомендацій, прийнятих за підсумками міжнародних конференцій у Грюнвальді, Тулузі, Відні, Севільї, Москві, Празі, Сеулі, які формулюють цілі і завдання для подальшого поширення медіа- та інформаційної грамотності і розвитку глобального інформаційного суспільства загалом. Зокрема, авторка звернула увагу на зміст та основні положення Празької декларації про створення суспільств інформаційної грамотності, Олександрійської декларації про інформаційну грамотність і неперервну освіту, Паризької декларації з розвитку медіаінформаційної грамотності для країн $\mathrm{OOH}$, Феської декларації щодо медіаінформаційної грамотності, Плану дій Глобального альянсу для партнерства 3 медіаінформаційної грамотності, Паризької декларації з медіаінформаційної грамотності в епоху цифрових технологій, Сеульської декларації про медіа- та інформаційну грамотність для всіх і у разі загальної участі: захист від дезінфодемії тощо. У текстах містяться заклики до урядів і неурядових організацій активно підтримувати і розвивати медіа- та інформаційну грамотність у всіх сферах життя і на всіх рівнях, акцентовано увагу на потребі постійного розвитку медіаосвіти та медіаграмотності як важливих елементів формування світогляду людини. ЮНЕСКО відіграє провідну роль в ініціативі щодо підтримки розробників інформаційних ресурсів з медіа- та інформаційної грамотності.
\end{abstract}




\title{
MEDIA AND INFORMATION LITERACY AS A STRATEGIC DIRECTION IN UNESCO'S ACTIVITY
}

\author{
Prykhodkina N. O. \\ Candidate of Pedagogical Sciences, Associate Professor, \\ Professor at the Department of Pedagogy, Administration and Special Education \\ University of Education Management of the National Academy of Pedagogical Sciences of Ukraine \\ Sichovykh Striltsiv str., 52 A, Kyiv, Ukraine \\ orcid.org/0000-0002-6211-5546 \\ prykhodkina2019@gmail.com
}

Key words: media, media and information literacy, UNESCO, UN, declaration, resolution.
The author analyzed the key documents of the UNESCO conferences, contributed to the development of media and information literacy in the world. UNESCO emphasizes the role of media literacy as an essential competence of the digital age. In the mid-70s, UNESCO declared not only its full support for media education, but also media education as a priority area for the coming decades. It is believed that the term "media education" was first used officially at the world level in 1973. During a joint meeting of the UNESCO Information Sector and the International Film and Television Council. In declarations and resolutions of international conferences, UNESCO emphasizes the importance of this area and defines media education as one of the priority areas of its activities. The researcher analyzed the content of declarations, resolutions and recommendations adopted as a result of international conferences in Grunwald, Toulouse, Vienna, Seville, Moscow, Prague, Seoul, which formulate goals and objectives for the further dissemination of media and information literacy and the development of the global information society as a whole. In particular, the author drew attention to the content and the main provisions of the Prague Declaration on the Creation of Information Literacy Societies, the Alexandria Declaration on Information Literacy and Lifelong Learning, the Paris Declaration on the Development of Media Information Literacy for UN Countries, the Feska Declaration on Media Information Literacy Action Plan of the Global Alliance for Partnership media literacy, Paris Declaration on Media Literacy in the Digital Age, Seoul Declaration on Media and Information Literacy for All and Participation: Protecting Against Disphodemia and the like. The texts contain calls for governments and non-governmental organizations to actively support and develop media and information literacy in all spheres of life and at all levels, emphasizing the need for continuous development of media education and media literacy as important elements in shaping a person's worldview. UNESCO is taking the lead in an initiative to support information resource developers with media and information literacy.
Постановка проблеми. Проблема підготовки людини до життя в інформаційному суспільстві перебуває у центрі уваги міжнародної спільноти i насамперед ЮНЕСКО, що у своїй діяльності підкреслює роль медіаграмотності як найважливішої компетенції цифрової епохи. Ця організація сприяє розвитку медіа- та інформаційної грамотності, що розглядається як «передумова для побудови інклюзивних, відкритих, партисипативних $\mathrm{i}$ плюралістичних суспільств знання» [17]. У численних резолюціях і на проведених міжнародних конференціях ЮНЕСКО підкреслює важливість цього напряму і в XXI ст. визначає медіаосвіту як один з їі пріоритетних напрямів.

У міжнародних конференціях і форумах різних рівнів, присвячених медіа- та інформаційній грамотності, зазвичай беруть участь не тільки представники різних комітетів ООН і ЮНЕСКО, а i федеральних і місцевих органів влади, інших державних структур, а також учені, експерти, фахівці з бібліотечної справи, що пропонують свої оцінки і рекомендації. За підсумками таких конференцій приймаються програмні документи, які формулюють цілі і завдання для подальшого поширення 
медіа- та інформаційної грамотності і розвитку глобального інформаційного суспільства загалом.

Мета статті - проаналізувати ключові документи за результатами міжнародних конференцій ЮНЕСКО, що сприяли розвитку медіа- та інформаційної грамотності у світі.

Виклад основного матеріалу. У середині 70-х років ЮНЕСКО заявило не тільки про свою повну підтримку медіаосвіти, а й про медіаосвіту як про пріоритетний напрям на найближчі десятиліття. Вважається, що термін «медіаосвіта» офіційно на світовому рівні вперше було використано у 1973 р. у процесі спільного засідання Сектору інформації ЮНЕСКО та Міжнародної ради 3 кіно та телебачення [1].

На початку 1980-х рр. ця організація оприлюднила текст офіційної доповіді з проблем глобальної комунікації (Many Voices, One World), відомої як звіт Макбрайда (MacBride Report, 1980). Початок розвитку медіаосвіти у світі було покладено 3 моменту прийняття представниками 19 націй на Міжнародному Симпозіумі ЮНЕСКО Грюнвальдської декларації з медіаосвіти ЮНЕСКО [4] в 1982 р. У декларації зазначено, що «замість того щоб засуджувати або схвалювати вплив медіа, нам потрібно визнати їх значний вплив і поширення по всьому світу, а також оцінити їх важливість як елемента культури у сучасному світі. Роль комунікації і медіа у процесі розвитку не слід недооцінювати, як і функції медіа як інструментів активної участі громадян у житті суспільства. Політичні та освітні системи повинні взяти на себе зобов'язання розвивати у своїх громадян критичне розуміння процесів комунікації» $[10$, с. 47]. Ці принципи знайшли практичне вираження у використанні моделі «культурного аналізу» медіатекстів (cultural analysis model) [11] на заняттях у закладах середньої та вищої освіти. Медіаосвіта була визначена найбільш ефективною, коли батьки, педагоги, журналісти та особи, відповідальні за прийняття рішень, усвідомлюють свою роль у розвитку критичного мислення в учнів, студентів, слухачів, глядачів і читачів.

У 1987 р. Рада Європи прийняла «Резолюцію 3 медіаосвіти і нових технологій», в якій була зазначена основна мета цього напряму в педагогіці: «медіаосвіта має починатися якомога раніше і тривати всі шкільні роки як обов'язковий для вивчення предмет». Медіаосвіта має готувати людей до життя в демократичному громадянському суспільстві, їм потрібно дати розуміння структури, механізмів і змісту медіа, розвивати в них здібності незалежного критичного оцінювання змісту медіа. «Визнаючи вирішальну роль медіа як телевізійного, радіо, кінематографічного, культурного досвіду дітей, медіаосвіта має починатися якомога раніше і тривати всі шкільні роки як обов'язковий для вивчення предмет» [8, с. 36].

У квітні 1997 р. у Парижі, в штаб-квартирі ЮНЕСКО, відбувся міжнародний науковий форум, що зібрав 350 учасників із 60 країн світу (крім усіх західноєвропейських і більшості латиноамериканських держав, були представлені США, Канада, Австралія, Японія, Індія, Росія та ін.). Генеральний директор ЮНЕСКО Ф. Майора (Federico Mayor) у своїй доповіді підкреслив актуальність і важливість медіа (телебачення, преси, кінематографу, комп'ютерних мереж) у сучасному світі, необхідність розвитку медіаосвіти дітей і молоді, наукових досліджень в аудіовізуальній сфері.

Учасниками конференції були відомі вчені-медіапедагоги 3 різних країн світу, зокрема, англомовних: Д. Букінгем (David Buckingham) та С. Лівінгстон (Sonia Livingstone) з Великобританії, А. Карон (Andre Caron), П'єр Беланже (Pierre Belanger), Д. Канкел (Dale Kunkel) та Ж. П'єт (Jacques Piette) зі Сполучених Штатів Америки, Д. Річардс (Debra Richars) з Австралії та ін.

У квітні 1999 р. у Відні відбулася міжнародна конференція 3 медіаосвіти «Освіта для медіа та цифрова ера» ("Educating for the Media and the Digital Age") [19], організована ЮНЕСКО та Міністерством освіти і культури Австрії. 3 доповідями про сучасний стан та перспективи медіаосвіти виступили 35 педагогів і вчених-дослідників з Австрії, Німеччини, Франції, США, Канади, Іспанії, Аргентини, Угорщини, Швеції, Південної Африки, Голландії, Індії, Югославії, Австралії, Бельгії, Данії, Великобританії, Росії та інших країн.

У Резолюції до конференції наголошувалося на необхідності включення курсів 3 медіаосвіти до програм закладів середньої та вищої освіти, медіаосвіта $\epsilon$ ключем до розвитку критичного i творчого мислення та невід'ємною частиною демократичного суспільства, пов'язаного з педагогікою, культурою, політикою і правами людини. Міністерством освіти і культури Австрії спільно з ЮНЕСКО було видано збірник матеріалів конференції «Медіаосвіта в інформаційний вік» [19].

ЮНЕСКО високо оцінює значимість продукції інформаційних технологій і важливість доступу до них. Відображенням цієї позиції стало створення у 2000 р. Міжурядової програми «Інформація для всіх» [14], націленої на об'єднання зусиль урядів різних країн світу для створення більш справедливого суспільства шляхом поліпшення доступу до інформації. «Програма «Інформація для всіх» - єдина міжурядова програма, цілком спрямована на просування загального доступу до інформації та знань в інтересах розвитку світової спільноти. Унікальність мандата програми та іï міжурядовий характер наділяють Міжурядову раду - керівний орган програми - повноваженнями на міжнародному 
рівні озвучувати іï стратегічні пріоритети, а також створювати й поширювати знання про використання інформаційно-комунікаційних технологій для розвитку» [6].

Діяльність у рамках Програми багато в чому сприяла тому, щоб 2003-2012 роки були оголошені Світовим десятиріччям грамотності Організації Об'єднаних Націй.

3 точки зору ЮНЕСКО інформація і знання стали рушійною силою соціальних перетворень. За умови систематичного і рівноправного використання і поширення необхідних інформації, знань i досвіду багато труднощів, з якими стикається людство, можуть бути істотно полегшені. Керуючись цим же принципом, учасники наради експертів, що пройшла під егідою ЮНЕСКО в Празі в 2003 р., прийняли декларацію «До інформаційно грамотного суспільства» (“Towards an Information Literate Society") [17]. Цей документ закликав уряди країн світу розробляти міждисциплінарні програми просування інформаційної грамотності, що $є$ необхідним кроком на шляху до формування грамотного населення, ефективного громадянського суспільства та конкурентоспроможної робочої сили. Хоча формально заклик адресований урядам, у вирішенні цього завдання повинні брати участь усі сектори суспільства.

Позиція ЮНЕСКО послідовно акцентує увагу на необхідності просування «від інформаційного суспільства до суспільства знання». Так, зокрема, називається перший розділ «Всесвітньої доповіді ЮНЕСКО. До суспільства знання», опублікований з урахуванням підсумків першої (Женевської) фази Всесвітнього саміту з питань інформаційного суспільства [17].

У світовій доповіді UNESCO «Назустріч суспільству знань» (Towards knowledge societies: UNESCO world report) підкреслюється, що глобальне інформаційне суспільство знайде свій сенс тільки в тому разі, якщо стане інструментом для досягнення більш піднесеної і бажаної мети створення в глобальному масштабі суспільства знання, здатного відкрити шлях до гуманізації процесу глобалізації.

Через 25 р. після прийняття Грюнвальдської декларації (1982), що ознаменувала становлення медіаосвіти на міжнародному рівні, експерти, функціонери, які визначають освітню політику, педагоги, дослідники, представники неурядових організацій 3 усіх регіонів світу зустрілися на Міжнародному симпозіумі ЮНЕСКО 3 медіаосвіти «Медіаосвіта - досягнення, перешкоди та нові тенденції з часів Грюнвальду: до масштабних змін?» (Media Education - Advances, Obstacles, and New Trends Since Grunwald: Towards a Scale Change?), що відбувся 21-22 червня 2007 р. у Парижі.
Головна мета конференції - виявити, як розвивається медіаосвіта в світі, які виникають труднощі на шляху реалізації такого роду освітньої політики та практичного досвіду, а також розробити практичні рекомендації щодо розвитку медіаосвіти.

Учасники конференції наголосили на важливості Грюнвальдської декларації і відзначили, що заяви, зроблені у 1982 р., у контексті інтенсивного розвитку інформаційного суспільства та глобалізації набувають особливої значущості. Значно зросли роль і місце медіа у сучасному суспільстві. Щоб краще адаптуватися до соціальних змін, суспільство має володіти навичками критичного аналізу інформації будь-яких символічних систем (образних, звукових, текстових), створення власних медіатекстів. До процесу медіаосвіти повинні бути залучені якомога більше іiі прихильників. Особлива актуальність Грюнвальдської декларації полягає як у ретельності проведеного аналізу, так і в підкресленні все ще недостатнього суспільного визнання необхідності медіаосвіти.

Результатом дводенної конференції стала розробка дванадцяти практичних рекомендацій [16], що сприяють виконанню чотирьох основних положень Грюнвальдської декларації: 1) розробка програм 3 медіаосвіти на всіх освітніх рівнях; 2) підготовка педагогів у галузі медіаосвіти і зростання інформованості про медіаграмотність усіх зацікавлених осіб та організацій у соціальній сфері; 3) проведення досліджень у галузі медіаосвіти i поширення їх результатів за допомогою мережевого мовлення; 4) міжнародне співробітництво в галузі медіаосвіти.

Ці рекомендації можуть використовуватися для всіх зацікавлених осіб на всіх рівнях упровадження, а також координації на місцевих національних, регіональних і міжнародних рівнях.

У рекомендаціях Севільського семінару «Медіаосвіта і молодь» 2002 р. говорилося про розвиток критичної медіаосвіти, підкреслювалося особливе значення розвитку критичної компетентності, здатності реагувати на будь-якого роду отриману інформацію і вміння користувачів захищати свої права. «Медіаосвіта - частина основного права кожного громадянина будь-якої країни на свободу самовираження та отримання інформації, воно сприяє підтримці демократії. Визнаючи відмінності в підходах і розвитку медіаосвіти в різних країнах, рекомендується, щоб вона була введена всюди, де можливо в межах національних навчальних планів, так само у рамках додаткової, неформальної освіти та самоосвіти протягом усього життя людини» [19, с. 152].

У тексті документа акцентовано увагу на потребі постійного розвитку медіаосвіти та медіаграмотності як важливих елементів формування світогляду людини. 
Про важливість вивчення питань медіаосвіти, iii ролі у процесі розвитку інформаційних технологій, становленні інформаційного суспільства, формування грамотної та обережної поведінки 3 інформацією як категорією йшлося також у Олександрійській декларації ЮНЕСКО «Про інформаційну грамотність та освіту протягом життя» (2005) [3]. Декларація була підписана неподалік від місця, де в давнину розташовувався Фароський маяк. Тому декларація метафорично позначила інформаційну грамотність як один 3 «маяків інформаційного суспільства» і як «основне право людини в цифровому світі», що дозволяє залучати до нього суспільства всіх націй. Крім того, така грамотність була представлена у вигляді «життєво важливого елементу» для окремих людей, малих i середніх підприємств, регіонів і націй загалом. Другим «маяком» стало вже згадане "Lifelong Learning"; разом же, на думку авторів декларації, вони «висвітлюють шляхи до розвитку, процвітання та свободи» [9].

У червні 2011 р. відбувся Перший міжнародний форум 3 медіа- та інформаційної грамотності (MIL). Форум був організований Університетом Сіді Мохамеда Бен Абделла за співпраці ЮНЕСКО як провідного партнера Ісламської Організації освіти, науки та культури (ISESCO), Арабського бюро освіти для країн Перської затоки (ABEGS) та Альянсу цивілізацій OOH (UNAoC) як ключових партнерів. Учасниками Форуму було прийнято Феську декларацію з медіа- та інформаційної грамотності [13], в якій звертається увага на необхідність розуміння взаємозв'язку між двома видами грамотності.

Основними рекомендаціями Феської декларації $з$ медіа- та інформаційної грамотності були:

- запровадити Всесвітній тиждень медіата інформаційної грамотності (МІГ) задля сприяння впровадженню МІГ у всьому світі. Було запропоновано відмічати цей тиждень 15-21 червня щороку. У 2012 р. ЮНЕСКО заснувала Глобальний тиждень медіа- та інформаційної грамотності, що об’єднує медіапедагогів, медіадослідників та всіх зацікавлених у поширенні медіа- та інформаційної грамотності як способу сприяння соціальній інтеграції та міжкультурного діалогу;

- забезпечити інтеграцію медіа- та інформаційної грамотності в освітні програми як у формальній, так і в неформальній освіті, щоб: а) забезпечити право кожного громадянина на громадянську освіту; б) розвинути навички критичного мислення та критичного аналізу; в) сформувати та розвинути медіакомпетентність учителів;

- включити виробництво та розповсюдження користувацького контенту (UGC), особливо молодіжних 3MI, як частину загальної структури MIL;
- дослідити стан розвитку інформаційної та медіаграмотності у різних країнах світу;

- розробити навчальну програму для вчителів щодо розвитку їхньої медіакомпетентності;

- заохочувати створення у всіх регіонах світу національних, регіональних та міжнародних інститутів або центрів для підтримки ініціатив щодо медіа- та інформаційної грамотності;

- схвалити створення регіонального Інституту або Центру з інформаційної та медіаграмотності в Університеті Сіді Мохамеда Бен Абделли (Фес, Марокко);

- організовувати міжнародний форум 3 медіата інформаційної грамотності кожні 2 роки. Наступний форум запланувати на березень/квітень 2013 р.;

- для розвитку міжкультурного діалогу, інформаційної та медіаграмотності створити мережу UNESCO-UNITWIN-MILID Network, залучивши університети-представники всіх регіонів світу.

24-28 червня 2012 р. була проведена Міжнародна конференція «Медіа і інформаційна грамотність у суспільствах знання» (село Судакова, Московська обл.). Основна мета конференції полягала в просуванні ідеї усвідомлення значущості, масштабу і необхідності формування медіа- та інформаційної грамотності на політичному рівні, в галузі освіти, ЗМІ, інформації та комунікації, а також серед широкої громадськості.

Учасники конференції висловили згоду з тим, що «медіа- та інформаційна грамотність лежить в основі всіх компетенцій і навичок, необхідних для ефективної роботи 3 досягнення Цілей розвитку тисячоліття ООН, Декларації ООН з прав людини і цілей, проголошених Світовим самітом 3 інформаційного суспільства». Вони підкреслили, що «медіа- та інформаційна грамотність $є$ необхідною умовою для сталого розвитку відкритих, плюралістичних, інклюзивних товариств знання, а також інститутів громадянського суспільства, організацій, спільнот і окремих осіб» [5, с. 2-3].

Основоположним питанням обговорення учасниками конференції стало питання розробки понятійного апарату i розуміння термінології медіа- та інформаційної грамотності. Очевидність міждисциплінарного дискурсу цієї проблематики, а також його неоднорідності, зумовленої професійними і культурними відмінностями фахівців, які брали участь в обговоренні, сприяла виявленню багатогранності поняття і різноманітності моделей системного формування інформаційної грамотності. Концепціям медіа- та інформаційної грамотності у суспільствах знання були присвячені доповіді першого дня конференції.

На підставі виступів пленарного засідання, а також за підсумками дискусії в рамках робочої групи під керівництвом голови Секції з інформа- 
ційної грамотності ІФЛА Марії Карме Торраса Кальво учасники підготували підсумковий документ конференції - «Декларацію про медіа- та інформаційну грамотність», в якій відобразили основні стратегічні напрями розвитку медіа- та інформаційної грамотності в усьому світі і дали їй консолідоване визначення.

Учасники Міжнародної конференції «Медіа та інформаційна грамотність у суспільствах знання» звернулися до урядів держав, організацій $\mathrm{OOH}$ (зокрема, ЮНЕСКО), міжурядових і громадських організацій, професійних асоціацій і установ освіти, науки, культури, соціальних інститутів, 3MI, мережевих об'єднань, представників комерційного сектору і індустрії із закликом: визнати, що медіа- та інформаційна грамотність має основоположне значення для благополуччя і розвитку особистості, спільнот, економіки і громадянського суспільства; включити розвиток медіа- та інформаційної грамотності в число пріоритетних напрямів національної політики в галузі освіти, культури, інформації, ЗМІ та ін.; включити медіата інформаційну грамотність і систему оцінки іiі рівня в навчальні програми на всіх рівнях освіти, в тому числі освіти протягом усього життя, навчання на робочому місці, підготовки і перепідготовки викладачів [5] тощо.

У 2013 р. були прийняті Рекомендації ЮНЕСКО-ІФЛА, в яких було запропоновано урядам і міжурядовим організаціям, а також приватним установам і організаціям слідувати стратегіям i програмам, котрі лобіюють і просувають медіата інформаційну грамотність, а також навчання протягом усього життя. Тим самим буде забезпечуватися необхідна база для реалізації цілей Декларації тисячоліття ООН [21] (United Nations Millennium Declaration).

У травні 2014 р. у штаб-квартирі ЮНЕСКО в Парижі проходив перший Європейський форум 3 питань медійної та інформаційної грамотності (МІГ). Учасники Форуму прийняли Паризьку декларацію 3 медіа- та інформаційної грамотності в епоху цифрових технологій [17] (2014р.). У декларації зазначено про важливість медіа- та інформаційної грамотності, зроблено акцент на ㄲï поширення в умовах сучасного цифрового середовища, «розумного використання інформаційно-комунікаційних технологій, важливості просування ідей грамотного поводження з інформацією у зв'язку із розбудовою громадянського суспільства» [2].

37 по 10 червня 2016 р. у Ханти-Мансійську в рамках Восьмого міжнародного IT-Форуму i Міжурядової програми ЮНЕСКО «Інформація для всіх» відбулася Міжнародна конференція «Медіаінформаційна грамотність і формування культури відкритого уряду». Конференція при- вернула увагу не тільки великих міжнародних експертів, а й уряди багатьох країн світу. Більше половини зі 110 учасників конференції були номіновані урядами своїх країн. Майже 50 країн були представлені на конференції провідними вченими, університетськими професорами, політиками, дипломатами, представниками органів державної влади, інститутів громадянського суспільства та приватного сектору.

Актуальність конференції була зумовлена необхідністю вирішення двох важливих завдань сучасності.

Перше завдання полягало в тому, щоб усіляко розвивати і на належному рівні підтримувати медіа- та інформаційні компетенції населення, які необхідні людям для того, щоб жити, розвиватися та ефективно функціонувати в умовах інформаційного середовища і бурхливого розвитку технологій.

На всіх рівнях - міжнародному, національному, регіональному, муніципальному - визнається необхідність залучення населення до управління, створення механізмів ефективного зворотного зв'язку, що можна зробити за допомогою формування систем відкритих урядів у кіберпросторі. Це друге важливе завдання.

Конференція ознаменувала новий важливий напрям розвитку медіаінформаційної грамотності в бік вирішення завдань формування відкритих урядів, створення механізмів зворотного зв'язку між урядами і суспільством.

3 листопада 2020 р. ЮНЕСКО опублікувала «Сеульську декларацію про медіа- та інформаційну грамотність для всіх і за загальної участі: захист від дезінфодемії», у якій було визначено пріоритети у цій галузі для державних структур, громадських організацій, закладів освіти і культури, бізнес-спільноти, усіх зацікавлених у розвитку і вдосконаленні медіа- та інформаційної грамотності в контексті боротьби 3 дезінфодемією [20] (введений ЮНЕСКО термін, утворений від слів «дезінформація» і «пандемія», тим самим підкреслює вплив неправдивої інформації на пандемію коронавірусу та іiї наслідки) [12].

У Сеульській декларації зазначено, що «медіата інформаційна грамотність не є панацеєю від усіх проблем, включаючи пандемію, але наполягаємо на тому, щоб медіа- та інформаційна грамотність отримала подальше визнання і оцінку в усіх освітніх, соціальних та економічних системах і застосовувалася як більш активний підхід до побудови стійкого і інклюзивного суспільства» [20]. Підвищення медіа- та інформаційної грамотності забезпечує розвиток критичного мислення людей і їх здатності розуміти та аналізувати, як відбувається їхня взаємодія з інформаційними та комунікаційними технологіями, зокрема, під час 
кризи. У декларації визначені загальні рекомендації для поширення медіа- та інформаційної грамотності в світі:

- поширювати медіа- та інформаційну грамотність 3 метою подолання перешкод до доступу до інформації та якісної освіти у зв'язку з пандемією COVID-19;

- залучати до участі в політиці медіа- та інформаційної грамотності компанії, що забезпечують інтернет-комунікації, міжнародні та регіональні організації, регулюючі органи влади, засоби масової інформації, представників громадянського суспільства, молоді та інших спільнот;

- пропагувати ініціативи медіа- та інформаційної грамотності щодо боротьби 3 дезінфодемією, зміною клімату тощо, свободи висловлення думок і доступу до інформації, що $є$ не тільки правами людини, але і частиною вирішення проблеми поширення дезінформації;

- включати питання медіа- та інформаційної грамотності в етичні стандарти компаній і організацій з метою забезпечення відкритого, інклюзивного та безпечного розвитку таких технологій, як штучний інтелект;

- підтримувати ініціативи медіа- та інформаційної грамотності в питаннях, що стосуються технологічного детермінізму [20].

Також у Сеульській декларації зазначені окремі рекомендації для: а) органів управління від державного до муніципального рівнів; б) громадянського суспільства, ЗМІ, молоді, академічних установ; в) приватного бізнесу, в тому числі телекомунікаційних компаній; г) ЮНЕСКО, інших установ ООН і дослідників.

Висновки та перспективи дослідження. Отже, ЮНЕСКО відіграє провідну роль перш за все у формуванні міжнародних мереж, обміні досвідом в галузі медіаосвіти. Політика ЮНЕСКО з питань медіаграмотності була зафіксована в документах, прийнятих за підсумками конференцій в Грюнвальді, Тулузі, Відні, Севільї, Москві, Празі, Сеулі та ін. Надалі ЮНЕСКО було прийнято низку декларацій, зокрема, Празьку декларацію про створення суспільств інформаційної грамотності, Олександрійську декларацію про інформаційну грамотність і неперервну освіту, Паризьку повістку дня - 12 рекомендацій $з$ розвитку медіаінформаційної грамотності для країн ООН, Феську декларацію щодо медіаінформаційної грамотності, Рамки і план дій Глобального альянсу для партнерства 3 медіаінформаційної грамотності, Паризьку декларацію 3 медіаінформаційної грамотності в епоху цифрових технологій, Сеульську декларацію про медіа- та інформаційну грамотність для всіх і за загальної участі: захист від дезінфодемії та ін. У текстах містяться заклики до урядів і неурядових організацій активно підтримувати i розвивати медіаінформаційну грамотність у всіх сферах життя і на всіх рівнях. ЮНЕСКО високо оцінює значимість продукції інформаційних технологій і важливість доступу до них. Відображенням цієї позиції стало створення у 2000 р. Міжурядової програми «Інформація для всіх». У контексті нового бачення процесу освіти ЮНЕСКО відіграє провідну роль в ініціативі щодо підтримки розробників інформаційних ресурсів з медіаінформаційної грамотності. Перспективи подальших розвідок у цьому напрямі ми вбачаємо у вивченні діяльності недержавних організацій та центрів англомовних країн щодо розвитку медіаграмотності громадськості.

\section{ЛІТЕРАТУРА}

1. Іванов В., Шкоба О. Медіаосвіта та медіаграмотність: визначення термінів. Інформаційне суспільство, 2012. № 16. С. 41-52.

2. Осюхіна М.О. Медіа- та інформаційна грамотність як складник сучасних інформаційнокомунікаційних обмінів (національна концепція у контексті світового досвіду) : дис. на здоб. ступеня канд. наук із соц. комунік. зі спец. : 27.00.01 «Теорія та історія соціальних комунікацій». Дніпро : Дніпровський національний університет імені Олеся Гончара. 2018. 319 с.

3. ЮНЕСКО. Александрийская декларация об информационной грамотности и образовании на протяжении всей жизни. 2005. URL: https://www.mediagram.ru/netcat_files/106/104/h_ec60754734ee $46 f 439 \mathrm{db} 048705 \mathrm{afd} 47 \mathrm{c}$.

4. ЮНЕСКО. Грюнвальдская декларация по медиаобразованию. 1982. URL: http://www.unesco.org/ education/pdf/MEDIA_E.PDF.

5. ЮНЕСКО. Московская декларация о медиа- и информационной грамотности: итоговый документ Междунар. конф. «Медиа- и информационная грамотность в обществах знания». Москва, 28 июня 2012 г. URL: http://www.unesco.org/new/fileadmin/MULTIMEDIA/HQ/CI/CI/pdf/In_Focus/Moscow_ Declaration_on_MIL_eng.pdf.

6. Юрченко О.А. Реалізація програми ЮНЕСКО «Інформація для всіх» в Україні. Бібліотекознавство. Документознавство. Інформологія, 2014. № 3, с. 66-71.

7. Austrian Federal Ministry of Education and Cultural Affairs \& UNESCO. Educating for the Media and the Digital Age. 1999. URL: https://www.mediamanual.at/en/pdf/educating_media_engl.pdf. 
8. Directorate General of Human Rights and the Rule of Law. Recommendations and Resolutions adopted by the Parliamentary Assembly of the Council of Europe in the field of media and information society. Strasbourg, 2015. URL: https://rm.coe.int/16806461f9.

9. IFLA. Beacons of the Information Society: The Alexandria Proclamation on Information Literacy and Lifelong Learning. 2005. URL: https://www.ifla.org/publications/beacons-of-the-information-societythe-alexandria-proclamation-on-information-literacy.

10. International Commission for the Study of Communication Problems. Many Voices, One World: the MacBride Report. 1980. URL: https://waccglobal.org/wp-content/uploads/2020/07/MacBride-ReportEnglish.pdf.

11. Mindful Media. Media, Semiotics, and Sociology: Three Models for Analysis. 2010. URL: http://mindfulmediablog.blogspot.com/2010/05/media-semiotics-and-sociology-three.html.

12. UNESCO Disinfodemic. 2020. URL: https://en.unesco.org/covid19/disinfodemic?fbclid=IwAR1I81f76_ uQLwJ3jGvlsfNOiz3inrMeLN6PWDWDgUR8vo4VZLvlWtEZj9c.

13. UNESCO. Fez Declaration on Media and Information Literacy. 2011. URL: http://www.unesco.org/new/ fileadmin/MULTIMEDIA/HQ/CI/CI/pdf/news/Fez\%20Declaration.pdf.

14. UNESCO. Information for All Programme (IFAP). 2001. URL: https://en.unesco.org/programme/ifap.

15. UNESCO. Media and Information Literacy. 2017. URL: http://www.unesco.org/new/en/communicationand-information/capacity-building-tools/media-and-information-literacy/.

16. UNESCO. Paris Agenda or 12 Recommendations for Media Education. 2007. URL: https://ifap.ru/pr/ 2007/070625ba.pdf

17. UNESCO. Paris Declaration on Media and Information Literacy in the Digital Era. 2014. URL: http://www.unesco.org/new/en/communication-and-information/resources/newsand-in-focusarticles/infocus-articles/2014/paris-declaration-on-media-andinformation-literacy-adopted/.

18. UNESCO. The Prague Declaration "Towards an Information Literate Society". 2003. URL: http://www.unesco.org/new/fileadmin/MULTIMEDIA/HQ/CI/CI/pdf/PragueDeclaration.pdf.

19. UNESCO. Recommendations Addressed to UNESCO on Media Education, Adopted by the Vienna Conference "Educating for the Media and the Digital Age". 1999. URL: http://www.nordicom.gu.se/sv/ clearinghouse/recommendations-addressed-unesco-media-education .

20. UNESCO. Seoul Declaration on Media and Information Literacy for Everyone and by Everyone: A Defence against Disinfodemics. 2020. URL: https://en.unesco.org/news/seoul-declaration-media-and-informationliteracy-everyone-and-everyone- 0 .

21. United Nations Human Rights: office of the high commissioner. United Nations Millennium Declaration. 2000. URL: https://www.ohchr.org/EN/ProfessionalInterest/Pages/Millennium.aspx.

22. World summit on the information society. Declaration of Principles. Building the Information Society: a global challenge in the new Millennium. 2003. URL: https:/www.itu.int/net/wsis/docs/geneva/official/ dop.html.

\section{REFERENCES}

1. Ivanov V., Shkoba, O. (2012). Mediaosvita ta mediahramotnist: vyznachennia terminiv [Media education and media literacy: definition of terms]. Informatsiine suspilstvo, No. 16. P. 41-52.

2. Osiukhina, M.O. (2018). Media- ta informatsiina hramotnist yak skladova suchasnykh informatsiinokomunikatsiinykh obminiv (natsionalna kontseptsiia u konteksti svitovoho dosvidu) [Media and information literacy as a component of modern information and communication exchanges (national concept in the context of world experience)] (PhD Thesis), Dnipro : Dniprovskyi natsionalnyi universytet im. Olesia Honchara.

3. UNESCO (2005). Aleksandrijskaya deklaracziya ob informaczionnoj gramotnosti i obrazovanii na protyazhenii vsej zhizni [Alexandria Declaration on Information Literacy and Lifelong Learning]. URL: https://www.mediagram.ru/netcat_files/106/104/h_ec60754734ee46f439db048705afd47c.

4. UNESCO (1982). Gryunval'dskaya deklaracziya UNESCO po mediaobrazovaniyu [UNESCO Grunwald Declaration on Media Education]. URL: http://www.unesco.org/education/pdf/MEDIA_E.PDF.

5. UNESCO (2012). Moskovskaya deklaracziya o media i informaczionnoj gramotnosti: itogoviy document Mezhdunarodnoy conf. "Media i informaczionnaya gramotnost"". Moskva, June 28, 2012. URL: $\quad$ http://www.unesco.org/new/fileadmin/MULTIMEDIA/HQ/CI/CI/pdf/In_Focus/Moscow_ Declaration_on_MIL_eng.pdf.

6. Iurchenko, O.A. (2014). Realizatsiia prohramy YuNESKO “Informatsiia dlia vsikh" v Ukraini [Implementation of the UNESCO program "Information for All" in Ukraine]. Bibliotekoznavstvo. Dokumentoznavstvo. Informolohiia, No. 3. Pp. 66-71. 
7. Austrian Federal Ministry of Education and Cultural Affairs \& UNESCO (1999). Educating for the Media and the Digital Age. URL: https://www.mediamanual.at/en/pdf/educating_media_engl.pdf.

8. Directorate General of Human Rights and the Rule of Law (2015). Recommendations and Resolutions adopted by the Parliamentary Assembly of the Council of Europe in the field of media and information society. Strasbourg, 2015. URL: https://rm.coe.int/16806461f9.

9. IFLA (2005). Beacons of the Information Society: The Alexandria Proclamation on Information Literacy and Lifelong Learning. URL: https://www.ifla.org/publications/beacons-of-the-information-society-thealexandria-proclamation-on-information-literacy.

10. International Commission for the Study of Communication Problems (1980). Many Voices, One World: the MacBride Report. URL: https://waccglobal.org/wp-content/uploads/2020/07/MacBride-Report-English. pdf.

11. Mindful Media (2010). Media, Semiotics, and Sociology: Three Models for Analysis. URL: http://mindfulmediablog.blogspot.com/2010/05/media-semiotics-and-sociology-three.html.

12. UNESCO (2020). Disinfodemic. URL:https://en.unesco.org/covid19/disinfodemic?fbclid=IwAR1I81f76_ uQLwJ3jGvlsfNOiz3inrMeLN6PWDWDgUR8vo4VZLvlWtEZj9c.

13. UNESCO (2011). Fez Declaration on Media and Information Literacy. URL: http://www.unesco.org/new/ fileadmin/MULTIMEDIA/HQ/CI/CI/pdf/news/Fez\%20Declaration.pdf.

14. UNESCO (2001). Information for All Programme (IFAP). URL: https://en.unesco.org/programme/ifap.

15. UNESCO (2017). Media and Information Literacy. URL: http://www.unesco.org/new/en/communicationand-information/capacity-building-tools/media-and-information-literacy/.

16. UNESCO (2007). Paris Agenda or 12 Recommendations for Media Education. URL: https://ifap.ru/pr/ 2007/070625ba.pdf.

17. UNESCO (2014). Paris Declaration on Media and Information Literacy in the Digital Era. URL: http://www.unesco.org/new/en/communication-and-information/resources/newsand-in-focusarticles/infocus-articles/2014/paris-declaration-on-media-andinformation-literacy-adopted/.

18. UNESCO (2003). The Prague Declaration "Towards an Information Literate Society". URL: http://www.unesco.org/new/fileadmin/MULTIMEDIA/HQ/CI/CI/pdf/PragueDeclaration.pdf.

19. UNESCO (1999). Recommendations Addressed to UNESCO on Media Education, Adopted by the Vienna Conference "Educating for the Media and the Digital Age". URL: http://www.nordicom.gu.se/sv/ clearinghouse/recommendations-addressed-unesco-media- education.

20. UNESCO (2020). Seoul Declaration on Media and Information Literacy for Everyone and by Everyone: A Defence against Disinfodemics. URL: https://en.unesco.org/news/seoul-declaration-media-andinformation-literacy-everyone-and-everyone- 0 .

21. United Nations Human Rights: office of the high commissioner (2000). United Nations Millennium Declaration. URL: https://www.ohchr.org/EN/ProfessionalInterest/Pages/Millennium.aspx.

22. World summit on the information society (2003). Declaration of Principles. Building the Information Society: a global challenge in the new Millennium. URL: https://www.itu.int/net/wsis/docs/geneva/ official/dop.html. 